INSTITUT AGAMA ISLAM IMAM GHOZALI (IAIIG) CILACAP

LPPM (Lembaga Penelitian dan Pengabdian Masyarakat)

Al-Muqkidz: Jurnal Kajian Keislaman

Jl. Kemerdekaan Barat No.17 Kesugihan-Cilacap || https://ejournal.iaiig.ac.id/index.php/amk Issn SK no.: 0005.235/JI.3.2/SK.ISSN/2012.07 || 0005.27158462/JI.3.1/SK.ISSN/2020.01

\title{
KONTEKSTUALISASI PENDIDIKAN ISLAM BERBASIS AL-QUR'AN DAN SIRAH NABAWIYAH DALAM SISTEM PENDIDIKAN DI INDONESIA
}

\author{
Lutfani \\ Institut Agama Islam Negeri Purwokerto \\ Email: luthfanaya@gmail.com
}

Naskah Diterima
12 Desember 2019

Publis Artikel

16 Januari 2020
Abstrak: Pendidikan merupakan hal yang sangat urgen yang harus selalu dikembangkan mengikuti zaman. Perkembangan zaman yang kian canggih berdampak pada perubahan perilaku moral yang semakin merosot, hal tersebut tentunya menjadi tantangan bagi pendidikan islam sendiri. Pendidikan islam bertujuan membentuk kepribadian yang lebih baik tanpa terpengaruh oleh perubahan zaman. Selain itu pendidikan islam juga harus mampu menyiapkan generasi yang cakap, sehingga mampu mengaplikasikan ajaran-ajaran agama islam dengan baik. Al-Qur'an sebagai pedoman bagi seluruh umat manusia juga harus dijadikan sebagai dasar dalam pelaksanaan pendidikan. Dengan berlandaskan Al-Qur'an, Hadits dan juga Ijtihad para ulama, pendidikan islam diharapkan mampu menjadi solusi atas fenomena-fenomena yang terjadi masa kini, karena pendidikan merupakan suatu faktor yang sangat mendukung bagi kemajuan suatu Negara.

\section{Kata kunci: Pendidikan Islam dan Al-Qur'an}

\section{A. Pendahuluan}

Pendidikan Islam adalah untuk membentuk kepribadian muslim atau juga sebagai perubahan tingkah laku dan sikap dan sikap tingkah laku tersebut haruslah sesuai dengan petunjuk yang ada di dalam ajaran Islam. ${ }^{1}$ Mengenai pengertian pendidikan Islam tersebut, Pendidikan memiliki posisi yang sangatlah penting dalam hidup dan kehidupan manusia, maka

\footnotetext{
${ }^{1}$ Zakiah Drajat, Ilmu Pendidikan Islam (Jakarta: Bumi Aksara, 2010) hal 28.
} 
Islam disini sebagai agama yang rahmatan lil'alamin, yang memberikan perhatian begitu serius terhadap perkembangan pendidikan, peserta didik dan bagi kelangsungan hidup. ${ }^{2}$

Dalam undang-undang no. 20 tahun 2003 secara tegas dinyatakan bahwa pendidikan agama merupakan bagian yang tak terpisahkan dari sistem pendidikan nasional. Setiap lembaga pendidikan mulai dari tingkat dasar sampai perguruan tinggi wajib memasukkan pendidikan agama sebagai muatan kurikulum. Pasal 37 ayat (1) menjelaskan bahwa pendidikan agama dimaksudkan untuk membentuk peserta didik menjadi manusia yang beriman dan bertaqwa kepada Tuhan Yang Maha Esa serta berakhlak mulia. ${ }^{3}$ Ada beberapa nilai fundamental dalam sumber pokok ajaran Islam yang harus dijadikan dasar bagi pendidikan Islam, yaitu: (1) Aqidah (2) Akhlak (3) Penghargaan kepada akal (4) Kemanusiaan (5) Keseimbangan (6) Rahmat bagi seluruh alam (Rahmatan lil'alamin). Pendidikan Islam dalam perencanaan, perumusan, dan pelaksanaannya pada pembentukan pribadi yang berakidah Islam, berakhlak mulia, berpikiran bebas, untuk mengarahkan dan mengembangkan potensi manusia secara terpadu tanpa ada pemisahan. Seperti aspek jasmani dan rohani, akal dan hati, individu dan sosial, duniawiah dan ukhrawiah, dan seterusnya. Karena pendidikan Islam mengarah pada pembentukan insan paripurna (insan kamil), yakni yang dapat menjadi Rahmatan Lil'alamin, mampu memerankan fungsinya sebagi Abdullah dan kholifatullah. ${ }^{4}$

Allah Swt menurunkan kitab suci Al-Qur'an bagi umat manusia khususnya kepada umat muslim sekaligus menjadi dasar dari Pendidikan Islam. Diharapkan agar pendidikan yang berlangsung itu berbasis Al-Qur'an. Konsep yang ada di dalam pendidikan Islam itu mencakup tarbiyah, ta'lim dan ta' din. Permasahan Yang ada di dalam pendidikan, bukan menjadi sebuah topik baru, melainkan sebuah hal yang harus di selesaikan. Begitu banyaknya permasalahan yang ada dan masalah yang sudah sangatlah memprihatinkan. Pendidikan yang di lakukan saat ini dalam menghadapi permasalahan yang sangat kompleks ${ }^{5}$, kompleks byang di maksud disini yaitu permasalahan yang berupa konseptual-teoritis dan praktis. ${ }^{6}$

\footnotetext{
${ }^{2}$ Robiatul Awwaliyah dan Hasan Baharun. "Pendidikan Islam dalam Sistem Pendidikan Nasional Telaah Epistemologi Terhadap Problematika Pendidikan Islam, “Online Jurnal of Didaktika, 19, no. 01 (Agustus 2018 ), 35 (diakses 03 November 2019).

${ }^{3}$ Undang-Undang RI No. 20 tahun 2003 tentang Sistem Pendidikan Nasional.

${ }^{4}$ Abidin Ibn Rusn, Pemikiran Al-Ghazali Tentang Pendidikan, Yogyakarta: Pustaka Pelajar, 1998, hal.132-133

${ }^{5}$ Ubay, Permasahan Pendidikan Islam, Wordpress, 07 Juni 2013 (diakses 03 November 2019).

${ }^{6}$ Ubay, Permasahan Pendidikan Islam..., 2
} 
Belum adanya penyelesaian masalah yang di hadapi menjadikan Pendidikan Islam tertinggal dari lembaga yang lain, sehingga Pendidikan terbaca sebagai pendidikan nomor dua. ${ }^{7}$ Ketertinggalan ini banyak di pengaruhi oleh beberapa faktor salah satunya yaitu sistem pendidikan yang ada di dalam pendidikan Islam masih berorientasi pada bidang humaniora. Nilai pembelajaran yang di berikan masih terfokus pada aspek kognitif dan penekanan pada aspek akhlak yang belum menyeluruh.

Hal ini tentunya memicu adanya pandangan bahwa pendidikan saat ini sudah begitu sakit, Pendidikan yang seharusnya dapat memanusiakan manusia malah justru belum mampu memanusiakan manusia seutuhnya sesuai dengan tujuan yang ada di dalam pendidikan Islam , yaitu Pendidikan yang seharusnya sesuai dengan Al-Qur'an yang pelaksanaannya sesuai dengan apa yang di cantumkan Nabi. Berbicara mengenai pendidikan Islam tentunya membawa kita semua pada hakikat pendidikan yang sebenarnya yaitu kembali kepada Al-Qur'an. Berikut pembahasan terkait Pendidikan Islam berbasis Al-Qur'an dan kenabian dalam sistem budaya pendidikan di Indonesia.

\section{B. Pengertian Pendidikan Islam.}

Pendidikan Islam sebagai suatu proses untuk mempersiapkan generasi yang disiapkan untuk mengisi banyak peranan seperti memindahkan pengetahuan-pengetahuan dan nilai- nilai Islam yang di sesuaikan dengan suatu fungsi manusia di dalam beramal di dunia agar mempunyai hasil yang baik di akhirat. ${ }^{8}$ Hal ini dapat ditarik kesimpulan bahwasanya Pendidikan Islam itu merupakan suatu proses, proses disini di fokuskan untuk membentuk individu yang berdasarkan pada ajaran Islam yang di wahyukan oleh Allah kepada Nabi Muhammad, melalui proses pendidikan Islam sehingga di harapkan adanya kebahagiaan dunia dan di akhirat. ${ }^{9}$ Pendidikan yang di arahkan disini yaitu Pendidikan yang berbasis kepada AlQur'an sesuai dengan dasar pendidikan yang ada yaitu Al-Qur'an, hadis dan ijtihad.

Setelah pemaparan tentang pengertian pendidikan, poin selanjutnya akan dibahas tentang konsep yang ada di dalam pendidikan Islam, beberapa konsep pendidikan Islam tersebut diantaranya yaitu;

\footnotetext{
${ }^{7}$ Ubay , Permasahan Pendidikan Islam..., 2

8 Robiatul Awwaliyah dan Hasan Baharun, "Pendidikan Islam dalam Sistem Pendidikan Nasional Telaah Epistemologi Terhadap Problematika Pendidikan Islam, "..., 94

9 Robiatul Awwaliyah dan Hasan Baharun, "Pendidikan Islam dalam Sistem Pendidikan Nasional Telaah Epistemologi Terhadap Problematika Pendidikan Islam, "...,94.
} 
a. Tarbiyah itu lebih cenderung untuk menyeluruh. Tarbiyah bermakna kepada mengajarkan dan melakukan. Tarbiyah sebagai hal yang menyeluruh karena Tarbiyah terkait hal yang diartikan sebagai membesarkan, memproduksi, mengasuh, mengembangkan, memberi makan memelihara dan menjinakkan. ${ }^{10}$ Istilah tarbiyah di ambil dari Fi 'il Madi- nya

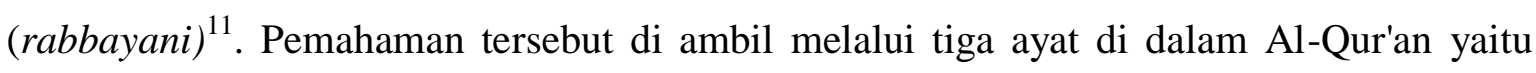
QS. Al-Baqarah 276, QS Asy- Syu'ara 18 dan Qs. Al-Isra' pada ayat 24

QS. Al-Baqarah 276:

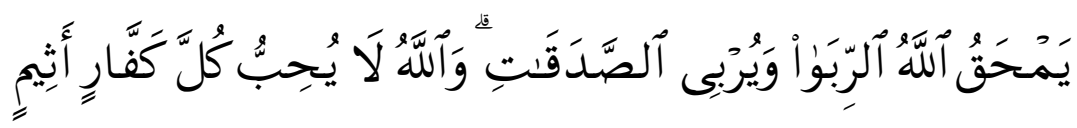

Artinya: Allah memusnahkan riba dan menyuburkan sedekah. dan Allah tidak menyukai setiap orang yang tetap dalam kekafiran, dan selalu berbuat dosa.

QS Asy- Syu'ara 18

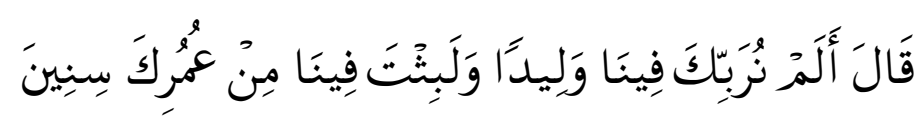

Artinya: Fir'aun menjawab: "Bukankah kami Telah mengasuhmu di antara (keluarga) kami, waktu kamu masih kanak-kanak dan kamu tinggal bersama kami beberapa tahun dari umurmu.

Qs. Al-Isra' 24

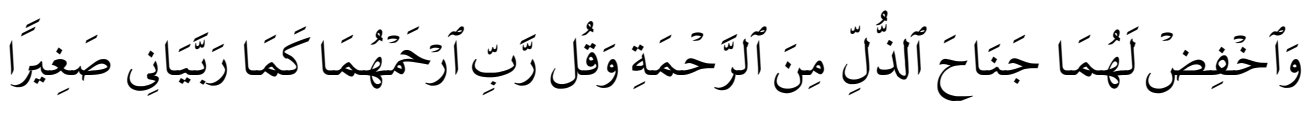

Artinya: Dan rendahkanlah dirimu terhadap mereka berdua dengan penuh kesayangan dan ucapkanlah: "Wahai Tuhanku, kasihilah mereka keduanya, sebagaimana mereka berdua Telah mendidik Aku waktu kecil".

Istilah Al Tarbiyah berasal dari kata $R a b b$, kata $R a b b$ memiliki begitu banyak arti.

Perlu kita ketahui bahwa makna dasarnya yaitu memelihara ${ }^{12}$, berkembang, tumbuh, mengatur dan menjaga eksistensinya (kelestarian). Secara etimologis juga kata "Al Tarbiyah" juga merupakan sebuah kata jadian dari tiga kata yaitu; ${ }^{13}$ Pertama, rabba-yarbu disini berarti bertambah, berkembang dan tumbuh. Pengertian yarba-yarbu disini

\footnotetext{
${ }^{10}$ Fuad Ifram Al-Bustamy Munjib Al Thullab (Beirut: Al Maktabah Asy- Syarkiyyah, 1980), 229.

${ }^{11}$ Diana Nur Sholihah, "Kontekstualisasi Pendidikan Islam dalam Al-Qur'an ,"Skripsi, (Surabaya: UIN Sunan Ampel, 2017), 26.

${ }_{12}$ Ibn Abdullah Muhammad bin Ahmad, Al Anshary Al - Qurthuby. Tafsir Al-Qurthuby Juz Satu (Kaito: adat Al Sya'by, t. Yg), 120 .

${ }^{13}$ Abu Al-Gadhu Al-bin Muhammad Mukarram IbnManzhut (Beirut: Drarr Agya, t. ATH) 94-96
} 
didasarkan dari Qs Al-Rum ayat 39. ${ }^{14}$ Pengertian al Tarbiyah pada poin pertama ini merupakan suatu proses menambahkan, mengembangkan dan menumbuhkan potensi yang ada di dalam peserta didik baik berupa fisik, psikis, sosial maupun spiritual. ${ }^{15}$ Kedua rabba- yarubbu tarbiyah kata ini berarti nasya'a (tumbuh) berubah menjadi dewasa atau besar. ${ }^{16}$ Ketiga rabba-yarubbu tarbiyah pun memiliki arti yang sama seperti pada poin yang pertama.

Abdurrahman Al Nahlawi berpendapat bahwa pengertian dari Pendidikan Islam yang tersirat dalam istilah al- tarbiyah meliputi empat unsur pendekatan yaitu memelihara dan menjaga serta fitrah. ${ }^{17}$ Peserta didik menjelang dewasa, mengembangkan selalu potensi peserta didik menuju kesempurnaan, mengarahkan selalu fitrah menuju kesempurnaan dan melaksanakan pendidikan secara terencana dan bercakap. ${ }^{18}$

Berdasarkan uraian tersebut di atas dapat disimpulkan bahwa al tarbiyah (Pendidikan) adalah suatu proses transformasi mengenai ilmu Pengetahuan dari pendidik kepada peserta didik agar peserta didik memiky semangat dan sikap yang tinggi di dalam menghadapi kehidupannya dan memahami kehidupannya, sehingga hasil akhirnya akan terbentuknya ketakwaan, keimanan, kepribadian yang luhur dan serta Budi pekerti.

b. $\mathrm{Al}$ Ta' Lim

Ta' lim lebih kepada mentransfer ilmu pengetahuan kepada peserta didik. Bisa juga disebut sebagai mengajar tanpa contoh. Ta'lim merupakan sebuah kata benda buatlah (mashdar) istilah tarbiyah itu diterjemahkan dengan arti Pendidikan sedangkan pada ta'lim disini diterjemahkan sebagai pengajaran. Hal ini dikarenakan kegiatan tersebut berupa mentransfer ilmu pengetahuan kepada peserta didik ' mengajar". ${ }^{19}$ Didalam Al-Qur'an dijelaskan bahwa Allah Swt mengajarkan manusia apa yang tidak diketahui. ${ }^{20}$ Ayat yang terkait dengan Pendidikan ta'lim pad QS. Al-A'laq 96:4. ${ }^{21}$

${ }^{14}$ AL QURAN

${ }^{15}$ Mappasiara, "Pendidikan Islam Pengertian Ruang Lingkup dan Epistemologisnya,"...,149.

${ }^{16}$ Abu Hurairah Ahmad Bin Faris Bin Zakaria, Mujam Maqayis Al-luhghah Juz II. Beirut: Dar Al Fikr,1979), 381384.

${ }^{17}$ M Qurais Shihab, Wawasan Al-Qur'an (Bandung: Mizan,1998), 284- 285.

${ }^{18}$ Abdurrahman al- Nahlawi, Prinsip- Prinsip dan Metode Pendidikan Islam (Bandung: Diponegoro, 1992), 32.

${ }^{19}$ Mustofa Rahman, Pendidikan Islam Prespektif Al-Qur'an (Yogyakarta: Pustaka Pelajar, 2001), 60.

${ }^{20} \mathrm{Al}$ A'laq 96: 5

${ }^{21} \mathrm{Al}$ a' laq 96: 4 
QS. Al-A'laq 96:4

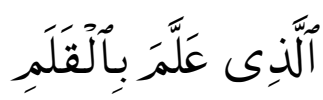

Artinya:Yang mengajar (manusia) dengan perantaran kalam,

QS. Al-Baqarah 2:31 22

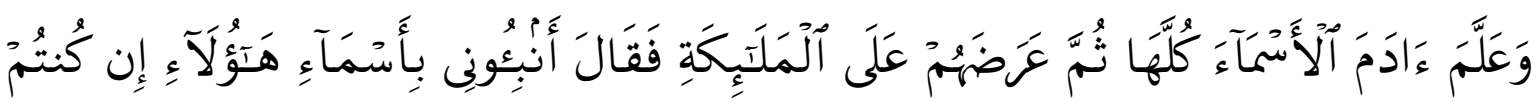

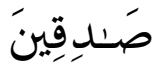

Artinya: Dan dia mengajarkan kepada Adam nama-nama (benda-benda) seluruhnya, Kemudian mengemukakannya kepada para malaikat lalu berfirman: "Sebutkanlah kepada-Ku nama benda-benda itu jika kamu mamang benar orang-orang yang benar!"

QS. An-Naml 27:16 ${ }^{23}$
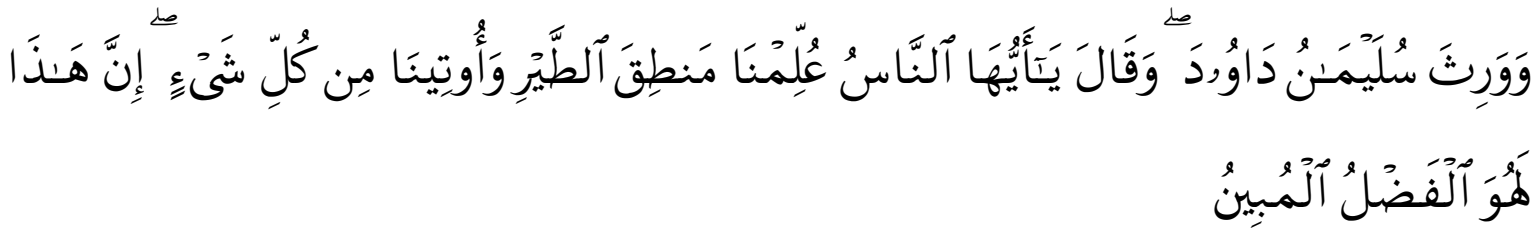

Artinya: Dan Sulaiman Telah mewarisi Daud, dan dia berkata: "Hai manusia, kami Telah diberi pengertian tentang suara burung dan kami diberi segala sesuatu. Sesungguhnya (semua) Ini benar-benar suatu kurnia yang nyata".

Jadi dapat disimpulkan Al-ta'lim didalam Al-Qur'an ditujukan sebagai sebuah proses pengajaran kepada peserta didik dan pemberian informasi.

c. Al-Ta' dib

Ta'dib berkaitan dengan etika. Berasal dari kata addaba, yuaddibu dan $t a^{\prime}$ diban. Lazimnya atau pada umumnya kata ta'dib diartikan dengan Pendidikan sopan santun sehingga hal ini berkaitan dengan akhlak. Ta'dib juga serumpun dengan adab yang mana hal ini berarti memiliki pendidikan kebudayaan dan peradaban. Hal ini dijabarkan bahwa artinya orang yang berpendidikan yaitu adalah orang yang berperadaban begitupun

\footnotetext{
${ }^{22}$ Al Baqarah 2:3

${ }^{23}$ Al-Naml 27: 16
} 
sebaliknya pula peradaban yang berkualitas itu diperoleh melalui sebuah jalur pendidikan. $^{24}$

Ta' dib secara mudah merupakan pemahaman tentang pengakuan dan pengenalan, hal ini terjadi secara berangsur- angsur yang di tanamkan kepada manusia terkait tempattempat yang tepat dari segala sesuatu di dalam tatanan penciptaan Allah yang sedemikian rupa, sehingga hal ini untuk membimbing kearah pengakuan kekuasaan dan pengenalan keagungan Allah didalam wujud dan keberadaan. ${ }^{25}$

Berdasarkan pada pemahaman tersebut Pendidikan Islam yang sudah disebutkan diatas yang diartikulasikan dengan tiga tema tersebut yaitu:

1) Al Tarbiyah

2) Al Ta'lim

3) Al Ta'dib

Maka kesimpulannya disini yaitu bahwa ketiga tema tersebut memang sudah mengisyaratkan Pendidikan. Analisis secara mendalam al ta'dib lebih banyak mengarah dan bermuara kepada penanaman nilai akhlak dan moral. Sedangkan Al Ta'lim lebih mengarah kepada aktivitas sebuah doktrinasi ketrampilan ilmu pengetahuan. ${ }^{26}$

\section{Fenomena Pendidikan Masa Kini}

Pendidikan adalah hal yang indah, keindahan proses belajar mengajar dengan menggunakan pendekatan manusia atau disebut sebagai " man centered ", Pendidikan bukan sekedar memindahkan otak dari kepala atau bahkan mengalihkan mesin ke tangan melainkan esensi pentingnya disini yaitu bahwa pendidikan lebih dari itu yaitu agar menjadikan manusia mampu untuk menaklukkan masa depan dan selalu dapat menaklukkan diri sendiri dengan didukung oleh daya Cipta, Karsa, Dzikir. ${ }^{27}$

Pendidikan pada hakikatnya akan memberikan kemampuan kepada manusia atau suatu komunitas, hal ini diperlukan bahwa pendidikan akan memberikan kemungkinan terbuka di

\footnotetext{
${ }^{24}$ Mustofa Rahman, Pendidikan Islam Prespektif Al-Qur'an..., 17.

${ }^{25}$ Bukhari Umar, Ilmi Pendidikan Islam (Jakarta: Sinar Grafika Offset, 2010), 29.

${ }^{26}$ As'arik Muhajir,'Tujuan Pendidikan Islam dalam Prespektif Al-Qur'an," Online Jurnal of Al Tahrir, 11, no. 02 (November 2011) 247 (diakses 03 November 2019).

27 Suyatno, "Dekonstruksi Pendidikan Islam Sebagai Subsistem Pendidikan Nasional" Online Jurnal of Pendidikan Islam, IV, no. $01 \quad$ (Juni 2015), 73 (diakses 03 November 2019).
} 
masa depan "bukan sebagai peramal". 28 Pendidikan Islam yang berlandaskan kepada AlQur'an, hadis dan ijtihad, namun pada kondisi sekarang ini yang tergambar justru berlainan dengan hal tersebut. Jikalaupun tidak berlainan hasil yang didapat belum mampu sesuai dengan yang diharapkan sesuai dengan tujuan yang ada di dalam pendidikan Islam. Perjalanan Pendidikan Islam seperti di Indonesia dihadapkan kepada berbagai masalah atau persoalan, persoalan tersebut tersaji kedalam hal yang multi kompleks dimulai dari yang konseptual hingga ke teoritis sampai dengan yang ke operasional praktis. ${ }^{29} \mathrm{Hal}$ ini terlihat dari adanya ketertinggalan Pendidikan Islam dengan Pendidikan lainnya baik dari segi kuantitas dan kualitasnya, sehingga Pendidikan selalu terkesan sebagai pendidikan berkelas dua. ${ }^{30}$

Fenomena Pendidikan saat ini tentunya sudah menjadi bahasan yang serius. Pendidikan saat ini terlalu sering atau bahkan difokuskan kepada kecerdasan Ilmu pengetahuan, peserta didik di fokuskan untuk menjadi pengusaha ilmu, lulusan dipersiapkan agar dapat bersaing dalam kancah dunia. Tentunya sangat baik, namun demikian belumlah cukup karena esensi yang sebenarnya dari Pendidikan adalah memanusiakan manusia, seharusnya adanya keseimbangan yang baik diantara keduanya. Sesuai dengan pengertian dari Pendidikan Islam Pendidikan Islam itu merupakan suatu proses yang difokuskan untuk membentuk individu yang berdasarkan pada ajaran Islam yang di diturunkan kepada Nabi Muhammad Saw, melalui proses pendidikan Islam sehingga di harapkan adanya kebahagiaan baik di dunia dan di akhirat. $^{31}$

Masalah yang sering sekali muncul saat ini dalah kemrosotan mental, akhlakul karimah yang dalam kesehariannya masih banyak nampak yang melakukan pelangaran-pelanggaran sebagaimana islam telah memberikan ajaran terhadap kaum muslimin pada khususnya, konsep pendidikan yang saat ini hanya di unggulkan umumnya saja padahal baik umum dan agama haruslah seimbang karena pendidikan agama (Al-Qur'an) adalah dasar dari berbagai disiplin ilmu.

\footnotetext{
${ }^{28}$ Ahamad Fauzi, Modem Manajamen Pendidikan Islam Telaah Pemikiran dan Tindakan Sosial (Probolinggo: At Ta'zim Inzah Genggong, 2017), 1-16.

${ }^{29}$ Robiatul Awwaliyah dan Hasan Baharun, "Pendidikan Islam dalam Sistem Pendidikan Nasional Telaah Epistemologi Terhadap Problematika Pendidikan Islam, "...,45

${ }^{30}$ Robiatul Awwaliyah dan Hasan Baharun, "Pendidikan Islam dalam Sistem Pendidikan Nasional Telaah Epistemologi Terhadap Problematika Pendidikan Islam, "...,45

${ }^{31}$ Robiatul Awwaliyah dan Hasan Baharun, "Pendidikan Islam dalam Sistem Pendidikan Nasional Telaah Epistemologi Terhadap Problematika Pendidikan Islam, "...,94.
} 


\section{Budaya Pendidikan Di Indonesia}

Budaya merupakan suatu kebiasaan yang diakui dan terjadi pada suatu wilayah, serta merupakan satu unsur yang tak dapat terpisahkan dari subyeknya. Setiap daerah maupun wilayah pasti memiliki budaya tersendiri, budaya inilah yang dapat menjadi pembeda antara wilayah satu dengan wilayah yang lain. Bahkan juga negara yang satu dengan negara yang lain. Sedangkan pendidikan sendiri merupakan suatu faktor penting bagi kemajuan suatu negara. Bahkan, terkadang pendidikan juga dijadikan sebagai tolak ukur kemajuan dan keberhasilan pengelolaan sumber daya manusia dalam suatu negara. Dan pastinya setiap negara mempunyai tata dan aturan tersendiri dalam mengatur pendidikan di wilayah mereka, dan berbeda beda pada setiap wilayahnya. ${ }^{32}$

Budaya pendidikan di Indonesia tidak lepas dari tradisi dalam penyampaian ilmu di masyarakat. Pada umumnya yang terjadi dikalangan masyarakat terdapat pemisahan antara pendidikan formal dan non formal. Akan tetapi sering menjadi permasalahan bahkan pertentangan antara keduanya. Hal tersebut sering kali terjadi dikalangan masyarakat kini terutama di daerah penulis yang pada umumnya masih memilah-milah pendidikan. Bahkan lebih parahnya saling bertentangan antara kebijakan pondok pesantren salaf yang meminta lebih di utamakan dibandingkan pendidikan formal pada umumnya. Padahal menuntut ilmu adalah suatu kewajiban bagi setiap umat, dan jauh dari abad yang lalu banyak para cendekiawan muslim yang mengkaji ilmu-ilmu yang sekarang dianggap sebagai umum atau kebarat-baratan.

Kemdian selain itu juga terdapat permasalahan yang lain yang bermunculan dalam dunia pendidikan di Indonesia yakni:

1. Pergantian Kurikulum

Telah diketahui khlayak umum, bahwa beberapa tahun terakhir ini budaya pendidikan Indonesia mulai berbenah. Dari yang dulunya menganut kurikulum KTSP dan berbasis teacher center kini telah beralih dengan menganut kurikulum 2013 yang berbasis student center. Tentunya perubahan ini tidak serta merta dapat diterima oleh masyarakat pendidikan. Banyak pro dan kontra yang mewarnai peluncuran kebijakan baru ini. Benar saja, dikarenakan Indonesia amatlah luas dengan keragaman yang ada pada setiap sisinya, hal ini membuat kebijakan pergantian kurikulum berbasis student center ini tidak dapat diterima di beberapa wilayah di Indonesia.

\footnotetext{
${ }^{32}$ Rosydatul istiqomah. Meneropong budaya pendidikan di Indonesia. Kompasiana. Uin malang
} 
Selain karena anggapan kurangnya fasilitas yang memadai, disisi lain juga ditambah dengan masih kurangnya profesionalitas guru dalam mengimplentasikan sisitem ini pada dunia pendidikan. Namun, seiring dengan berjalannya waktu penerapan kurikulum 2013 mulai bisa difungsikan di beberapa sekolah diseluruh Indonesia. Dan dengan penerapan kurikulum ini, diharapkan pendidikan Indonesia makin berkelas dan bermutu, sehingga dapat menghasilkan sunber days manusia yang aktif, kreatif dan mempunyai days saing yang kuat di kancah lokal, nasional, maupun international.

2. Full Day School

Masih dengan suatu kebijakan baru, pemerintah juga telah mengeluarkan peraturan baru yaitu full dayschool. Dengan tujuan agar nantinya pelajar mempunyai waktu weekend yang lebih dengan keluarga. Jika biasanya sekolah hanya sampai siang pada hari seninsabtu, dengan kebijakan ini jam pelajaran ditambah sampai sore dan hari sekolah dipangkas menjadi senin-jum'at saja. Dibeberapa instansi pendidikan umum kebijakan ini tidak begitu banyak mengundag sebuah kontradiksi, namun di beberapa instans pendidikan keagamaan sempat terdapat kontradiksi dengan adanya kebijakan ini. Dikarenakan dikebanyakan madrasah setiap harinya pulang sekolah kurang lebih pukul 15.00 WIB. Karena tambahan beberapa mata pelajaran agama di setiap madrasah. Disamping itu, mereka beranggapan pula jika pembelajaran dilakukan sampai terlalu sore, maka hal ini juga dapat memotong beberapa waktu anak-anak untuk belajar di TPQ.

3. Pendidikan Karakter

Akhir-akhir ini santer sekali terdengar berbagai berita yang menjadi tamparan keras bagi pendidikan Indonsia. Wajar saja, karena saat ini pendidikan Indonesia telah diancam oleh rusaknya pendidikan karakter para pelajarnya. Hal ini sudah menjadi rahasia umum bagi masyarakat Indonesia, berbagai bukti robohnya karakter serta moral para pelajar saat ini dengan mudahnya dapt diakses melalui kecanggihan tekhnologi saat ini. Lalu, apakah berbagai hal ini saat ini telah menjadi budaya pendidikan yang terbaru di Indonensia.

Jika dahulu murid sangat hormat pada sang guru, kini mereka bahkan berani menjebloskan guru mereka kepenjara bahkan menganiaya guru nya sampai kehilangan nyawa. Jika dahulu pelajar tingkat SD masih polos dengan yang namanya percintaan, saat ini justru seolah-olah pelajar SD sudah faham betul dan seeing memperagakan adegan yang seharusnya belum mereka ketahui dengan usia mereka yang masih anak-anak. Jika dahulu 
anak-anak lebih suka bermain diluar rumah dan menjalin interaksi dengan teman sebaya mereka, saat ini di tunjang dengan kemajuan tekhnologi kebanyakan dari mereka dibuat lebih asyik sendiri dirumah, dibanding dengan bermain bersama teman-teman mereka diluar rumah.

Tentunya dengan berbagai fenomena peralihan karakter dan moral anak sekarang, bukan sepenuhnya tanggung jawab dari lembaga pendidikan. Melainkan tanggung jawab dari seluruh aparatur negara serta masyarakat, bagaimana berbagai orang yang ada disana dapat saling bekerja sama untuk memperbaiki lagi karakter pelajar masa kini, membantu para tokoh pendidikan sebagai pemeran utama dalam membangun dan membentuk karakter bangsa.

Pada dasarnya memang telah banyak terjadi pergeseran, pembaharuan, bahkan perubahan dalm budaya pendidikan yang ada di Indonesia. Namun, juga tetap harus difahami bahwa semua itu harus tetap berlandaskan pada pancasila sebahai semboyan nilainilai bangsa Indonesia, agar bangsa Indoenesia tidak kehilangan jati diri bangsa sendiri, karena terkikis dengan budaya lain. Budaya mungkin boleh saja berubah, namun nilai-nilai pendidikan Indonesia tidak boleh berubah. Haruslah menjadi tanggung jawab bersama dalam memertahankan nilai-nilai tersebut baik dari pemerintah, masyarakat dan utama nya para pendidikan yang berinteraksi langsung dengan para pelajar, utamanya guru agama dan guru BK. Karena kebiasaan (budaya) wajar saja berubah sesuai dengan keadaan, situasi, dan kondisi saat itu. Karena sebuah resotorasi itu perlu untuk kemjauan pendidikan Indoensia. Dan diharapkan setiap perubahan yang terjadi dalam budaya pendidikan di Indonesia mempunyai dampak positif bagi pendidikan sendiri.

\section{E. Kesimpulan}

Pendidikan Islam itu merupakan suatu proses, proses disini di fokuskan untuk membentuk individu yang berdasarkan pada ajaran Islam yang di wahyukan oleh Allah kepada Nabi Muhammad, melalui proses pendidikan Islam sehingga di harapkan adanya kebahagiaan dunia dan di akhirat. Konsep pendidikan Islam tersebut diantaranya yaitu;

Tarbiyah itu lebih cenderung untuk menyeluruh. Tarbiyah bermakna kepada mengajarkan dan melakukan. Al tarbiyah (Pendidikan) adalah suatu proses transformasi mengenai ilmu Pengetahuan dari pendidik kepada peserta didik agar peserta didik memiky 
semangat dan sikap yang tinggi di dalam menghadapi kehidupannya dan memahami kehidupannya, sehingga hasil akhirnya akan terbentuknya ketakwaan, keimanan, kepribadian yang luhur dan serta Budi pekerti.

1. $\mathrm{Al} \mathrm{Ta'} \mathrm{Lim}$

Ta' lim lebih kepada mentransfer ilmu pengetahuan kepada peserta didik. Bisa juga disebut sebagai mengajar tanpa contoh. Ta'lim merupakan sebuah kata benda buatlah (mashdar) istilah tarbiyah itu diterjemahkan dengan arti Pendidikan sedangkan pada ta'lim disini diterjemahkan sebagai pengajaran.

2. Al-Ta' dib

Ta'dib berkaitan dengan etika. Berasal dari kata addaba, yuaddibu dan ta' diban. Lazimnya atau pada umumnya kata ta'dib diartikan dengan Pendidikan sopan santun sehingga hal ini berkaitan dengan akhlak.

Fenomena Pendidikan Saat ini Pendidikan pada hakikatnya akan memberikan kemampuan kepada manusia atau suatu komunitas, hal ini diperlukan bahwa pendidikan akan memberikan kemungkinan terbuka di masa depan " bukan sebagai peramal". Pendidikan Islam yang berlandaskan kepada Al-Qur'an, hadis dan ijtihad, namun pada kondisi sekarang ini yang tergambar justru berlainan dengan hal tersebut. Jikalaupun tidak berlainan hasil yang didapat belum mampu sesuai dengan yang diharapkan sesuai dengan tujuan yang ada di dalam pendidikan Islam

Perjalanan Pendidikan Islam seperti di Indonesia dihadapkan kepada berbagai masalah atau persoalan, persoalan tersebut tersaji kedalam hal yang multi kompleks dimulai dari yang konseptual hingga ke teoritis sampai dengan yang ke operasional praktis. Hal ini terlihat dari adanya ketertinggalan Pendidikan Islam dengan Pendidikan lainnya baik dari segi kuantitas dan kualitasnya, sehingga Pendidikan selalu terkesan sebagai pendidikan berkelas dua. Hal ini sungguhlah hal yang ironis mengingat masyarakat Indonesia yang mayoritas beragama Islam.

Fenomena Pendidikan saat ini tentunya sudah menjadi bahasan yang serius. Pendidikan saat ini terlalu sering atau bahkan difokuskan kepada kecerdasan Ilmu pengetahuan, peserta didik di fokuskan untuk menjadi pengusaha ilmu, lulusan dipersiapkan agar dapat bersaingdi kancah dunia. Tentunya hal ini sangat baik namun bekum cukup karena esensi yang sebenarnya dari Pendidikan adalah memanusiakan 
manusia, seharusnya adanya keseimbangan yang baik diantara keduanya. Sesuai dengan pengertian dari Pendidikan Islam Pendidikan Islam itu merupakan suatu proses, proses disini di fokuskan untuk membentuk individu yang berdasarkan pada ajaran Islam yang di wahyukan oleh Allah kepada Nabi Muhammad, melalui proses pendidikan Islam sehingga di harapkan adanya kebahagiaan dunia dan di akhirat.

Kritik yang saya paparkan disini lebih kepada segi pembelajaran pendidikan. Pendidikan Islam diakui keberadaannya dalam sistem pendidikan. Selain itu permasalahan lainnya juga tentang adanya pendikotomian Ilmu pengetahuan. Dikotomi pendidikan juga menguat kembali akibat gejolak politik nasional yang bermuatan ideologi tertentu.

\section{DAFTAR PUSTAKA}

Abdurrahman al- Nahlawi. 1992. Prinsip- Prinsip dan Metode Pendidikan Islam Bandung: Diponegoro

Abidin Ibn Rusn, 1998 Pemikiran Al-Ghazali Tentang Pendidikan, Yogyakarta: Pustaka Pelajar

Ahmad Bin Faris Bin Zakaria. 1979. Abu Hurairah. Mujam Maqayis Al-luhghah Juz II Beirut: Dar Al Fikr

Akmansyah, M. " Al-Qur'an dan Al-Sunnah Sebagai Dasar Ideal Pendidikan Islam". Online Jurnal of Pengembangan Masyarakat Islam, 08, no. 02 (Agustus 2015), 128 (diakses 03 November 2019).

Al-Gadhu Al-bin Muhammad Mukarram IbnManzhut,. Abu.Beirut: Drarr Agya, t. Ath

al- Nahlawi, Abdurrahman. 1992. Prinsip- Prinsip dan Metode Pendidikan Islam. Bandung: Diponegoro.

Awwaliyah, Robiatul dan Hasan Baharun,"Pendidikan Islam dalam Sistem Pendidikan Nasional Telaah Epistemologi Terhadap Problematika Pendidikan Islam." Online Jurnal of Didaktika. 19, no. 01 (Agustus 2018), 35 (diakses 03 November 2019).

Diana Nur Sholihah, 2017. " Kontekstualisasi Pendidikan Islam dalam Al-Qur'an ,". Skripsi,.Surabaya: UIN Sunan Ampel.

Drajat, Zakiah. 2010. Ilmu Pendidikan Islam. Jakarta: Bumi Aksara,.

Fauzi, Ahamad. Modem Manajamen Pendidikan Islam Telaah Pemikiran dan Tindakan Sosial. Probolinggo: At Ta'zim Inzah Genggong, 2017.

Ifram Al-Bustamy Munjib Al Thullab, Fuad. 1980. Beirut: Al Maktabah Asy-Syarkiyyah,

Ismail Ali, Said dalam Hasan Langgulung (Ed), op, Cut.

Jannah, Fathul. "Pendidikan Islam Dalam Sistem Pendidikan Nasional", OnlineJurnal of Dinamika. 13.no. 02, (Desember 2013),164 (diakses 04 November 2019).

Jannah, Fathul. "Pendidikan Islam dalam Sistem Pendidikan Nasional."Online Jurnal of Dinamika Ilmu. 13, no.02 (Desember 2013) 164 (diakses 03 November 2019).

Mappasiara, " Pendidikan Islam Pengertian Ruang Lingkup dan Epistemologisnya." Online Jurnal of Pendidikan Islam, VII, no. 01(Januari- Juni 2018), 157 (diakses 02 November 2019).

Muhajir, As'arik. " Tujuan Pendidikan Islam dalam Prespektif Al-Qur'an,"'Online Jurnal of Al Tahrir. 11, no. 02 (November 2011) 247 (diakses 03 November 2019). 


\section{Lutfani; "KONTEKSTUALISASI PENDIDIKAN ISLAM BERBASIS AL-QUR'AN DAN SIRAH NABAWIYAH DALAM SISTEM PENDIDIKAN DI INDONESIA"}

Muhammad bin Ahmad, Ibn Abdullah. Al Anshary Al-Qurthuby Tafsir Al-Qurthuby Juz Satu. Kaito: adat Al Sya'by, t. Yg.

Nizar, Samsul. 2011. Dasar Dasar Pemikiran Pendidikan Islam. Jakarta:Gaya Media Pratama.

Rahman,Mustofa.2001. Pendidikan Islam Prespektif Al-Qur'an. Yogyakarta: Pustaka Pelajar.

Robiatul Awwaliyah dan Hasan Baharun, " Pendidikan Islam dalam Sistem Pendidikan Nasional Telaah Epistemologi Terhadap Problematika Pendidikan Islam, "..

Shihab, M Qurais. 1998.Wawasan Al-Qur'an. Bandung: Mizan.

Suyatno, " Dekonstruksi Pendidikan Islam Sebagai Subsistem Pendidikan Nasional," Online Jurnal of Pendidikan Islam. IV, no. 01 (Juni 2015), 73 (diakses 03 November 2019).

Ubay, Permasahan Pendidikan Islam. Wordpress, 07 Juni 2013 (diakses 03 November 2019).

Umar, Bukhari. Ilmi Pendidikan Islam. Jakarta: Sinar Grafika Offset, 2010.

Undang-Undang RI No. 20 tahun 2003 tentang Sistem Pendidikan Nasional.

Zakiah Drajat 2010, Ilmu Pendidikan Islam. Jakarta: Bumi Aksara, 